\title{
Investigating Social Class Inequality in Malcolm Bradbury's Eating People Is Wrong
}

\author{
Noureddine Friji \\ English Language Institute, King Abdulaziz University \\ Jeddah, Saudi Arabia
}

\begin{abstract}
Like race and gender, social class continues to engender controversy and to engage political and intellectual debate. As is the case with cultural, historical and socialist studies, fictional works tend to attend to the tensions and pretensions marking social class relations. A case in point is Malcolm Bradbury's university novel Eating People Is Wrong (1952), which, homing in on the intricacies and intimacies of academic life, details the struggle of a working-class student called Louis Bates to gain tolerance and prominence in an inhospitable environment populated by pretentious and allegedly superior characters. While tackling these concerns, the present paper laments the prevalence of base and biased practices. These practices are all the more shameful as they are associated with academics and intellectuals, who should naturally join forces to help establish an inclusive environment which tolerates diversity, to poke away at the clogged channels of communication between people from all walks of life and to signpost the direction for the public. Coming out strongly against discrimination and calling for the advancement of universally welcome values like integrity and integration, the paper concludes that however hard it is for the members of disadvantaged social classes to overcome the shattering and fettering prejudice displayed by so-called arbiters of taste and style, universities can still help attain and maintain equality among their populations and among their respective societies thanks to the continual survival, if in residual form, of liberal humanistic ideas and ideals.
\end{abstract}

Keywords: affectation, class-consciousness, liberal, social class, working-class

Cites as: Friji, N. (2019). Investigating Social Class Inequality in Malcolm Bradbury's Eating People Is Wrong. Arab World English Journal for Translation \& Literary Studies3 (4) 3-18. DOI: http://dx.doi.org/10.24093/awejtls/vol3no4.1 